UDC 349.22:331.106.4

DOI https://doi.org/10.26661/hst-2021-8-85-10

\title{
LEGAL REGULATION PROBLEMS OF EMPLOYMENT CONTRACT TERMINATION ON EMPLOYER'S INITIATIVE
}

\author{
(c) PERKUMIENĖ, DALIA \\ E-mail: perkum@gmail.com \\ ORCID iD: 0000-0003-4072-3898 \\ Kazimieras Simonavičius University Dariaus ir Girèno g. 21, Vilnius, Lithuania 02189
}

(C) BERIOZOVAS, OLEGAS

E-mail: olegas.beriozovas@ksu.1t ORCID iD: 0000-0003-3254-7215

Kazimieras Simonavičius University Dariaus ir Girèno g. 21, Vilnius, Lithuania 02189

(C) STANIONIENE், EGLE்

E-mail: stanion.ee@gmail.com

ORCID iD: https://orcid.org/0000-0002-8710-291X

Kazimieras Simonavičius University Dariaus ir Girèno g. 21, Vilnius, Lithuania 02189

\begin{abstract}
Abstarct.
The relevance of this study. The establishment of labor relations in today's society is one of the main guarantors of material well-being, or more precisely financial situation, and security. Having a job makes a person feel safe, which in turn affects more productive and higher-performing work. Yet it often happens that a person loses this guarantor of his or her security and material well-being and is fired. The large numbers of unemployed people registered in Lithuania show that job loss and related unemployment is one of the problems of the whole society. In Lithuania alone in 2018. 148,242 unemployed were registered in 2019, and in 2019 - 144989 [1]. According to the data of the Employment Service, in 2021. January 1 There were 277,100 unemployed in Lithuania, which is 16.1 percent. of the total working age population of the country.

The main problem. The direct impact of quarantine bans and the general economic slowdown are leading to an increase in the number of terminations. Termination of the employment contract at the request of the employee or by agreement between the employee and the employer is sufficiently clear to the institutes of employment law [2]. In the context of a pandemic, it is considered that an employee, as a weaker party to an employment relationship, may not only lose a stable source of income due to a closed business, but may also abuse the employer's statutory right to dismiss workers. conditions for these workers to return to work. The following tasks: 1 . To define the concept of an employment contract terminated at the initiative of the employer. 2. To examine the essential aspects of the legal regulation of the employment contract upon its termination at the initiative of the employer. 3. Identify the problems of legal regulation of the employment contract after its termination at the initiative of the employer. 4. To analyze the problems of the employment contract after its termination at the initiative of the employer in court practice. The aim of this work to analyze the main problems of legal regulation and application of the employment contract after its termination at the initiative of the employer. The paper concluded that ttermination of an employment contract is the termination of the rights and obligations of the parties to the employment contract, regardless of who initiates the termination of this relationship. Meanwhile, the termination of the employment contract at the initiative of the employer is the end of the relationship between the parties to the employment contract when the employer is given the right to initiate the termination of this relationship. The novelty Although several scientific articles can be found on termination of employment, a more detailed and in-depth analysis of termination at the initiative of the employer is lacking. In view of this, the novelty. As the result the regulation of dismissal of an employee, when the right of initiative to terminate the employment relationship is transferred to the "hands" of the employer, is quite comprehensive and ensures the existence of fair treatment of the employee. The used methodology document analysis, systematic analysis, comparative, logicalanalytical method, and generalization methods.
\end{abstract}

Keywords: employer, employee, employment contract, termination, employer initiative.

\section{Statement of the problem.}

Analyzing the problematic situation regarding the termination of the employment contract, terminating it at the initiative of the employer can raise the following main problems: first, the problems arise from the application of the termination of the employment contract at the will of the employer, since the employer has a discretion to terminate the employment contract for any reason. secondly, the employer has the right to dismiss the employee without stating any reason 
for dismissal and the Labor code of the Republic of Lithuania does not provide that the reason for dismissal must be important. thirdly, it should be noted that the list of what constitutes a serious breach of duty is not exhaustive, so that the employer may abuse his right to identify other cases of a serious breach in internal documents.

Relevance of the topic the establishment of labor relations in today's society is one of the main guarantors of material well-being, or more precisely financial situation, and security. Having a job makes a person feel safe, which in turn affects more productive and higher-performing work. Yet it often happens that a person loses this guarantor of his or her security and material well-being and is fired. Termination of the employment contract at the request of the employee or by agreement between the employee and the employer is sufficiently clear to the institutes of employment law.

Meanwhile, termination of the employment contract at the initiative of the employer is a much more complex institute, especially after 2017. on 1 July, when the new provisions governing the termination of the employment contract at the initiative of the employer entered into force. For this reason, the extension of the framework of employer initiative in legal norms is relatively new, therefore the mechanism of application of these norms has not been fully examined in detail. In view of this, the novelty of the topic in question is manifested in the fact that the work reveals exactly one way of terminating the employment contract, i. y. termination at the initiative of the employer.

The aim of the research is to analyze the main problems of legal regulation and application of the employment contract after its termination at the initiative of the employer.

\section{Results.}

Labor relations are one of the main safeguards of human well-being. Employment provides a wage that individuals can take care of their own and their loved ones' well-being. One of the objectives of labor law is to ensure employment security, so that if labor law were free to apply without restriction the provisions of contract law which leave the parties free to determine the conditions for terminating contracts, it is clear that that objective would never be achieved. Labor law therefore provides for the protection of employees in the event of termination of their employment contract at the initiative of the employer, in particular in the case of dismissal through no fault of the employee. In Lithuania, the main national legal acts on termination of an employment contract are the Labor Code and the Constitution. Article 48 of the Constitution states that "everyone is free to choose his or her job and business, and has the right to decent, safe and healthy working conditions, to a fair wage and to social security in the event of unemployment" [3].

The concept of the institution of termination of employment in national and international law

Since a legal employment relationship arises only based on an employment contract, the termination or termination of the employment contract is also considered to be the end of the legal employment relationship and, at the same time, the end of the rights and obligations of their subjects. The concepts of termination and termination of an employment contract defined in the Labor Code of the Republic of Lithuania (hereinafter - the Labor Code of the Republic of Lithuania) are not identical. The concept of termination of an employment contract is broadest, as it covers all cases of termination of an employment contract, and thus of an employment relationship, when essentially all rights and obligations of the parties to the employment contract, regardless of the person's initiative. terminated. It should be noted that the new LC of the Republic of Lithuania does not provide a detailed list of grounds for termination of an employment contract, thus the employer has more freedoms to terminate the employment contract with the employee. [4]. Lithuanian labor relations are regulated not only by national but also by international legal acts. 1919 The International Labor Organization established in 2006, is the only specialized agency of the United Nations operating on a tripartite basis (governments, workers, employers). The main goal of this organization is to increase social justice for working people [5]. This organization envisages international policies and programs to improve working and living conditions and develops international labor standards. Being a member of the said organization obliges to respect and nurture the principles of world importance in labor legal relations and to ensure their real implementation and functioning in the domestic labor law of the state. As in national and international law, the institution of termination of employment is important. One of the safeguards against unjustified dismissal is a warning. The purpose of the alert is to help the employee adapt and allow time to look for a new job. ILO Convention no. 158 [6] "On termination of employment at the initiative of the employer" Art. speaks of a notice of termination of employment and provides that the dismissed worker must be given 
notice within a reasonable time, but does not specify its duration, and the employer is given the option of not complying with that time limit and paying compensation not specified in the Convention. It must be emphasized that, following a notice of termination, the employment contract remains in force and the parties must fulfill their obligations until the employment contract expires. The fact that an employment contract is coming to an end does not entitle either the employee or the employer to perform their duties more negligently.

In order to discuss the regulation of termination of employment at international level, it is important to mention the Universal Declaration of Human Rights [7], adopted in 1948. December 10 If 23 Art. $1 \mathrm{~d}$. refers to the right of individuals to work and their choice - it is a dispositive norm that allows a person to choose a job of his or her own free will and regulates to ensure working conditions and protection against unemployment. The Convention for the Protection of Human Rights and Fundamental Freedoms (ECHR) [8], which entered into force in 1950 and established the European Court of Human Rights (ECtHR), is also important in the debate. Lithuania has ratified this Convention; therefore its provisions are directly applicable. Mention should also be made of the European Social Charter adopted in 1996. on 3 May, with a view to guaranteeing workers' rights and their protection. In the present case, Article 24 of the Charter is relevant, which guarantees the right to protection in the event of termination of an employment contract [9].

The concept of termination of the employment contract at the initiative of the employer.

According to the Labor Code of the Republic of Lithuania, an employer may dismiss an employee on his or her own initiative due to the employee's fault (Article 58 of the Labor Code of the Republic of Lithuania) or without the employee's fault (Article 57 of the Labor Code of the Republic of Lithuania) [10]. In order for an employer to say goodbye to employees fairly and lawfully, the employer must meet certain conditions. If it is planned to dismiss a group of employees [11], before deciding on dismissal of employees, the employer must perform information and consultation procedures of the employees' representatives (Article 207 of the Labor Code of the Republic of Lithuania). If individual employees are dismissed, but the decision will have a significant impact on the organization of work in the company and the situation of employees, consultation and information procedures are performed in accordance with Article 208 of the Labor Code of the Republic of Lithuania [11].

Although the norms of the Labor Code of the Republic of Lithuania provide for cases of dismissal, when an employer may dismiss an employee on his or her own initiative, at the same time this legal act also establishes certain guarantees for employees. For example, the prohibition to dismiss an employee under Article 57 of the Labor Code of the Republic of Lithuania. Pregnant workers, including those raising young children under the age of 3 and those called up for military service, cannot be dismissed on this basis [12].

Breach of guaranteed rates is considered an independent ground for declaring an employee's dismissal illegal. Thus, an employer may dismiss a person on his own initiative due to the employee's fault and without fault, in accordance with the relevant articles of the Code of the Republic of Lithuania. Upon termination of employment at the initiative of the employer without the employee's fault, the employer must pay the employee the benefit provided for in Article 57 of the Labor Code of the Republic of Lithuania. $8 \mathrm{p}$. The employer is obliged to notify the employee of imminent dismissal. Such a decision must be notified within the time limits established by law. LR LK 57 p. 1 d. 1 p. and 3 p. the grounds for dismissal based on which the employment contract may be terminated when the employee's work functions become redundant, when the employee refuses to work in the event of changes in the terms of the contract. It should be noted that changes in the organization of work and other reasons related to the activities of the employer allow to state that the work function performed by the employee becomes excessive for the employer, i. y. becomes redundant [13]. Excess work performed by an employee may be recognized when the employer completely relinquishes the work function performed by the employee or when it is determined that fewer employees are sufficient to perform the same or similar functions. Excessive work function can be caused by both internal and external reasons. Internal reasons may include reorganization of work organization, and external reasons may include economic or other external reasons why the employer decides to reduce the company's operating costs [14].

In Australia, at the initiative of the employer, the employment contract is terminated when the employer's actions "directly and indirectly" result in termination of employment and if the employer 
had not taken such action, the employee would have remained in employment [15]. The question arises as to whether the employer's actions lead to a "direct or consequential" termination of employment, which is important but not essential [16]. The actual or subjective intention of the employer is irrelevant. Contracting the employment contract does not automatically terminate the contract, but the injured party has the right to terminate the contract [17].

Termination of employment not only traumatizes employees, but loss of income has a direct impact not only on the well-being of the employee but also on his or her family. As more countries seek employment flexibility and globalization destabilizes traditional employment patterns, it is likely that more and more workers will be forced to retire at some point in their working lives. At the same time, flexibility in reducing the number of employees and laying off dissatisfied employees is a necessary tool for employers to maintain the productivity of the company [18].

In Belgium, for example, regarding termination of employment contracts and social welfare, employment contracts are usually terminated by giving notice of dismissal or compensation in lieu of notice. It is also possible to combine the two cases where, after service of the notice period, a benefit is paid for the remaining notice period [19]. The employer does not need any permission to dismiss the employee (except for the dismissal of an employee representative or prevention counselor). Following the recent reform of Belgian labor law, the notice periods for blue-collar and white-collar workers are now in line with employment contracts, which come into force in 2014. From January 1. these notice periods are set by law and depend only on the employee's length of service [20]. Contracts of indefinite duration valid until 2014 From 1 January 2006, the notice period to be observed in the event of dismissal shall consist of two parts, which shall be aggregated [21].

Under Irish law, people who have lost their job can be entitled to unemployment benefit, and those with sufficient social security contributions can receive jobseeker's allowance, and those who do not have sufficient PRSI contributions can receive jobseeker's allowance. Depending on all the circumstances, a person may also receive a medical card or a general practitioner business card and other ancillary benefits, such as a rent supplement under the supplementary welfare benefit scheme [22].

In summary, the termination of an employment contract is understood as the termination of the rights and obligations of the parties to the employment contract, regardless of who initiates the termination of this relationship. Comprehensive regulation, both at national and international level, ensures that the rights of the worker as a weaker party to the employment relationship are not violated. Clear regulation of the cases in which termination of employment contracts may be initiated by the employer, and in particular the existence of a requirement to state the reason for termination of employment, is considered a safeguard for the rights of employees and, in some cases, employees with specific characteristics. Ensuring workers' rights when an employment contract is terminated is necessary to preserve a person's emotional and financial stability. Financial instability is seen as a major social consequence of dismissal, as the person who has lost his or her job feels insecure and inferior due to public attitudes. For this reason, in the event of financial instability, the state's treatment of a person who has lost his job is considered as "first aid". In the form of various benefits and allowances, it provides at least the minimum social guarantees for the unemployed person.

\section{Conclusions.}

1. Termination of an employment contract is the termination of the rights and obligations of the parties to the employment contract, regardless of who initiates the termination of this relationship. Meanwhile, the termination of the employment contract at the initiative of the employer is the end of the relationship between the parties to the employment contract when the employer is given the right to initiate the termination of this relationship.

2. Comprehensive regulation of employer-terminated termination of employment at both national and international level ensures that the employee's rights as a weaker party to the employment relationship are not violated. Ensuring their rights is essential to preserving a person's emotional and financial stability.

3. The regulation of dismissal of an employee, when the right of initiative to terminate the employment relationship is transferred to the "hands" of the employer, is quite comprehensive and ensures the existence of fair treatment of the employee.

4. The existence of problematic situations in dismissal is revealed by the extensive case law on dismissal at the initiative of the employer. Problematic situations arise from the gross assessment of a breach of duty. The list of serious violations established by the labor code of the Republic of Lithuania is not exhaustive, therefore the employer reserves the right to decide on the seriousness of a specific 
violation. There are cases where the infringement is found to be serious, but the dismissal is found to be disproportionate to the infringement committed. Situations when an employee is dismissed at the will of the employer create a medium for litigation, as the labor code of the Republic of Lithuania does not establish specific reasons for dismissal and the employer may dismiss the employee with a large margin of discretion. There are also cases of non-compliance by employers with certain guarantees for some employees. Employers often do not apply the guarantees of priority to stay at work established by the Labor Code of the Republic of Lithuania and dismiss an employee.

\section{Список використаних джерел}

1. Registered unemployed. Lithuanian official statistics. Internet access: https://osp.stat.gov.lt/statistiniu-rodikliuanalize?indicator $=$ S3R813\#/, [viewed 0501 2021], last visited 2021-05-15.

2. Termination of employment: what do employers and employees need to know in the face of COVID-19? Internet access: https://www.vz.lt/verslo-valdymas/2020/04/27/darbo-sutarties-nutraukimas-ka-siuo-metu-turi-zinoti-darbdaviaiir-darbuotojai, last visited 2021-04-28.

3. Constitution of the Republic of Lithuania (No. 220-0 of 30 November 1992). Valstybès žinios, 1992, No.33-1014.

4. Davulis, T. (2018). Commentary on the Labor Code of the Republic of Lithuania. Vilnius: Center of Registers.

5. Žilionis, M., (2016). The New Labor Code: How Conditions for Employees Will Change. Vilnius: Delfi.lt. Internet access: https://www.delfi.lt/verslas/verslas/naujas-darbo-kodeksas-kaip-keisis-salygos-darbuotojams.d?id=71633036, [accessed 10 February 2021].

6. 1982 ILO Convention no. 158 Termination of the employment contract at the initiative of the employer. Available online: http://www.ilo.org/ilolex/english/convdisp1.htm, [accessed 10/02/2021].

7. Universal Declaration of Human Rights and Freedoms, adopted on 10 December 1948. Valstybès žinios, 2006-06-17, No. 68-2497.

8. European Convention for the Protection of Human Rights and Fundamental Freedoms, adopted on 4 November 1950. Valstybès žinios, 1995-05-16, No. 40-987.

9. European Social Charter adopted on 3 May 1996 Valstybès žinios, 2001-06-08, No. 49-1704.

10. Žukaite, R. (2020). How to say goodbye to an employee correctly at the initiative of the employer? Internet access: https://vedlys.ey.com/news-and-articles/how-to-right-welcome-with-the- Employee-Employer-initiative, [viewed 10.01.2021].

11. Labor Code of the Republic of Lithuania (No. XII-2603 of 14 September 2016). TAR, 19/09/2016, no. 23709, $63 \mathrm{p}$.

12. Employment-contract-termination, Business News (2020). Internet access: https://www.vz.lt/verslovaldymas/2020/04/27/darbo-sutarties-nutraukimas-ka-siuo-metu-turi-zinoti-darbdaviai-ir-darbuotojai, _ [accessed 10 March 2021].

132015 Handbook on European Law on the Rights of the Child. Accessed via internet: http://publications.europa.eu/ resource/cellar/f5e4f4b6-8e87-11e5-b8b7-01aa75ed71a1.0016.03/DOC_1, last visited 2021-05-18.

14. Mikalopas, M. (2020). Termination of the employment contract at the initiative of the employer through no fault of the employee. Internet access: https://www.15min.lt/naujiena/aktualu/nuomones/mantas-mikalopas-darbo-sutartiesnutraukimas-darbdavio-iniciatyva-nesant-darbuotojo-kaltes-18-1356330, [accessed 10 March 2021].

15. Australian case Mohazab v Dick Smith Electronics Pty Ltd No. 2 IRCA 645 [(1995) 62 IR 200 at p. 205]. Internet access: http://www7.austlii.edu.au/cgi-bin/viewdoc/au/cases/cth/IRCA/1995/645.html, [accessed 202103 10].

16. Australian case Barkla v G4S Custodial Services Pty Ltd [2011] No. FWAFB 3769. Internet access: https://www. fwc.gov.au/documents/decisionssigned/html/2011fwafb3769.htm, [accessed 202103 12].

17. Australian Labor Court Case Elgammal v BlackRange Wealth Management Pty Ltd [2011] FWAFB 4038 (Harrison SDP, Richards SDP, Williams C, 30 June 2007). Internet access: https://www.fwc.gov.au/documents/decisionssigned/ html/2011fwafb4038.htm, [accessed 10 March 2021].

18. International Labour Standards on Employment security, (2021). Accessed via internet: https://www.ilo.org/ global/standards/subjects-covered-by international-labour-standards/employment-security/lang--en/index.htm, [accessed $20210310]$.

19. Employment law overview Belgium 2019-2020. Accessed via internet: https://knowledge.leglobal.org/wp-content/ uploads/sites/2/LEGlobal-Employment-Law-Overview_Belgium_2019-2020.pdf, [accessed 202102 18].

20. Boreham, P. et. al. (2013). An alternative measure of social wellbeing: Analysing the key conceptual and statistical components of quality of life. Australian Journal of Social Issues, T. 48, p. 151-172.

21. Employment law overview Belgium 2019-2020. Accessed via internet: https://knowledge.leglobal.org/wp-content/ uploads/sites/2/LEGlobal-Employment-Law-Overview_Belgium_2019-2020.pdf, [accessed 202102 18].

22. Losing your job. Accessed via internet: https://www.citizensinformation.ie/en/employment/unemployment_and redundancy/losing_your_job/losing_your_job.html\#, [accessed 202103 08]. 


\section{References}

1. Registered unemployed. Lithuanian official statistics. Internet access: https://osp.stat.gov.lt/statistiniu-rodikliuanalize?indicator=S3R813\#/, [viewed 0501 2021], last visited 2021-05-15.

2. Termination of employment: what do employers and employees need to know in the face of COVID-19? Internet access: https://www.vz.lt/verslo-valdymas/2020/04/27/darbo-sutarties-nutraukimas-ka-siuo-metu-turi-zinoti-darbdaviaiir-darbuotojai, last visited 2021-04-28.

3. Constitution of the Republic of Lithuania (No. 220-0 of 30 November 1992). Valstybės žinios, 1992, No.33-1014.

4. Davulis, T. (2018). Commentary on the Labor Code of the Republic of Lithuania. Vilnius: Center of Registers.

5. Žilionis, M., (2016). The New Labor Code: How Conditions for Employees Will Change. Vilnius: Delfi.lt. Internet access: https://www.delfi.lt/verslas/verslas/naujas-darbo-kodeksas-kaip-keisis-salygos-darbuotojams.d?id= 71633036, [accessed 10 February 2021].

6. 1982 ILO Convention no. 158 Termination of the employment contract at the initiative of the employer. Available online: http://www.ilo.org/ilolex/english/convdisp1.htm, [accessed 10/02/2021].

7. Universal Declaration of Human Rights and Freedoms, adopted on 10 December 1948. Valstybès žinios, 2006-06-17, No. 68-2497.

8. European Convention for the Protection of Human Rights and Fundamental Freedoms, adopted on 4 November 1950. Valstybès žinios, 1995-05-16, No. 40-987.

9. European Social Charter adopted on 3 May 1996 Valstybės žinios, 2001-06-08, No. 49-1704.

10. Žukaitè, R. (2020). How to say goodbye to an employee correctly at the initiative of the employer? Internet access: https://vedlys.ey.com/news-and-articles/how-to-right-welcome-with-the- Employee-Employer-initiative, [viewed 10.01.2021]

11. Labor Code of the Republic of Lithuania (No. XII-2603 of 14 September 2016). TAR, 19/09/2016, no. 23709,63 p.

12. Employment-contract-termination, Business News (2020). Internet access: https://www.vz.lt/verslovaldymas/2020/04/27/darbo-sutarties-nutraukimas-ka-siuo-metu-turi-zinoti-darbdaviai-ir-darbuotojai, [accessed 10 March 2021].

132015 Handbook on European Law on the Rights of the Child. Accessed via internet: http://publications.europa.eu/ resource/cellar/f5e4f4b6-8e87-11e5-b8b7-01aa75ed71a1.0016.03/DOC_1, last visited 2021-05-18.

14. Mikalopas, M. (2020). Termination of the employment contract at the initiative of the employer through no fault of the employee. Internet access: https://www.15min.lt/naujiena/aktualu/nuomones/mantas-mikalopas-darbo-sutartiesnutraukimas-darbdavio-iniciatyva-nesant-darbuotojo-kaltes-18-1356330, [accessed 10 March 2021].

15. Australian case Mohazab v Dick Smith Electronics Pty Ltd No. 2 IRCA 645 [(1995) 62 IR 200 at p. 205]. Internet access: http://www7.austlii.edu.au/cgi-bin/viewdoc/au/cases/cth/IRCA/1995/645.html, [accessed 20210310$].$

16. Australian case Barkla v G4S Custodial Services Pty Ltd [2011] No. FWAFB 3769. Internet access: https://www.fwc.gov.au/documents/decisionssigned/html/2011fwafb3769.htm, [accessed 202103 12].

17. Australian Labor Court Case Elgammal v BlackRange Wealth Management Pty Ltd [2011] FWAFB 4038 (Harrison SDP, Richards SDP, Williams C, 30 June 2007). Internet access: https:/www.fwc.gov.au/documents/decisionssigned/ html/2011 fwafb4038.htm, [accessed 10 March 2021].

18. International Labour Standards on Employment security, (2021). Accessed via internet: https://www.ilo.org/ global/standards/subjects-covered-by international-labour-standards/employment-security/lang--en/index.htm, [accessed $20210310]$.

19. Employment law overview Belgium 2019-2020. Accessed via internet: https://knowledge.leglobal.org/wp-content/ uploads/sites/2/LEGlobal-Employment-Law-Overview_Belgium_2019-2020.pdf, [accessed 20210218 ].

20. Boreham, P. et. al. (2013). An alternative measure of social wellbeing: Analysing the key conceptual and statistical components of quality of life. Australian Journal of Social Issues, T. 48, p. 151-172.

21. Employment law overview Belgium 2019-2020. Accessed via internet: https://knowledge.leglobal.org/wp-content/ uploads/sites/2/LEGlobal-Employment-Law-Overview_Belgium_2019-2020.pdf, [accessed 20210218 ].

22. Losing your job. Accessed via internet: https://www.citizensinformation.ie/en/employment/unemployment_and_ redundancy/losing_your_job/losing_your_job.html\#, [accessed 20210308$].$

ПЯРКУМЕНЕ, ДАЛЯ - Доц. проф., Доктор юридичних наук, Університет імені Казиміраса Симонавічуса (Каунас, Литва)

E-mail: perkum@gmail.com

ORCID: 0000-0003-4072-3898 
БЕРЕЗОВ, ОЛЕГ - Докторант з праву, Декан юридичного факультету,. Университет імені Казиміраса Симонавічуса (Вильнюс, Литва)

E-mail: olegas.beriozovas@ksu.lt

ORCID iD: 0000-0003-3254-7215

CTАНІОНЕНЕ, ЕГЛЕ - Магістр права, Університет імені Казиміраса Симонавічуса (Каунас, Литва) E-mail: stanion.ee@gmail.com

ORCID iD: https://orcid.org/0000-0002-8710-291X

\title{
ПРОБЛЕМИ ПРАВОВОГО РЕГУЛЮВАННЯ ПІСЛЯ ПРИПИНЕННЯ ТРУДОВОГО ДОГОВОРУ З ІНІЦІАТИВИ РОБОТОДАВЦЯ
}

\begin{abstract}
Анотація.
Актуальність дослідження. Встановлення трудових відносин у сучасному суспільстві - один з головних чинників матеріального благополуччя, а точніше фінансового становища, безпеки. Робота змушує людину відчувати себе у безпеці, що, у свою чергу, впливає на більш продуктивну і результативну роботу. Але часто трапляється, що людина втрачає цього гаранта своєї безпеки і матеріального благополуччя і звільняється. Велика кількість безробітних, зареєстрованих в Литві, свідчить про те, що втрата роботи і пов'язане з нею безробіття є однією з проблем всього суспільства. Тільки у Литві в 2018 р в 2019 році було зареєстровано 148242 безробітних, а в 2019 р - 144989. За даними Служби зайнятості, у січні 2021 року в Литві було 277100 безробітних, що становить 16,1 відсотків від загальної чисельності населення країни у працездатному віці. Головна проблема. Прямий вплив карантинних заборон і загальний економічний спад призводять до збільшення числа звільнень. Розірвання трудового договору на прохання працівника або за згодою між працівником і роботодавцем досить ясно для інститутів трудового права. В контексті пандемії вважається, що працівник, як більш слабка сторона у трудових відносинах, можуть не тільки втратити стабільне джерело доходу через закриття бізнесу, але також може зловживати законним правом роботодавця звільняти працівників. Умови для повернення цих робочих на роботу. Вирішено наступні завдання: 1. Визначити поняття трудового договору, що припиняється з ініціативи роботодавця. 2. Вивчити істотні аспекти правового регулювання трудового договору при його розірванні за ініціативою роботодавця. 3. Виявити проблеми правового регулювання трудового договору після його розірвання з ініціативи роботодавця. 4. Проаналізувати проблеми трудового договору після його розірвання з ініціативи роботодавця в судовій практиці. Метою даної роботи $є$ аналіз основних проблем правового регулювання та застосування трудового договору після його розірвання з ініціативи роботодавця. У статті зроблено висновок, що припинення трудового договору $є$ припиненням прав і обов'язків сторін трудового договору, незалежно від того, хто ініціює припинення цих відносин. Тим часом припинення трудового договору з ініціативи роботодавця $є$ закінченням відносин між сторонами трудового договору, коли роботодавцю надається право ініціювати припинення цих відносин. Новизна. Незважаючи на те, що можна знайти ряд наукових статей про припинення трудових відносин, більш детальний і глибокий аналіз звільнень 3 ініціативи роботодавця відсутній. Зважаючи на це, с таття має реальну новизну. В результаті регулювання звільнення працівника, коли право ініціативи з припинення трудових відносин переходить в «руки» роботодавця, $€$ досить всеосяжним і забезпечує існування справедливого ставлення до працівника. Використана методологія аналіз документів, системний аналіз, порівняльний, логіко-аналітичний метод і методи узагальнення.
\end{abstract}

Ключові слова: роботодавець, працівник, трудовий договір, розірвання, ініціатива роботодавця.

ПЯРКУМЕНЕ, ДАЛЯ - Доц. проф., Доктор юридических наук, Университет имени Казимираса Симонавичуса (Каунас, Литва)

E-mail: perkum@gmail.com

ORCID: 0000-0003-4072-3898

БЕРЕЗОВ, ОЛЕГ - Докторант по праву, Декан юридического факультета. Университет имени Казимираса Симонавичуса (Вильнюс, Литва)

E-mail: olegas.beriozovas@ksu.lt

ORCID iD: 0000-0003-3254-7215

СТАНИОНЕНЕ, ЭГЛЕ - Магистр права, Университет имени Казимираса Симонавичуса (Каунас, Литва)

E-mail: stanion.ee@gmail.com

ORCID iD: https://orcid.org/0000-0002-8710-291X

Legal regulation problems of employment contract termination on employer's initiative 


\title{
ПРОБЛЕМЫ ПРАВОВОГО РЕГУЛИРОВАНИЯ ПОСЛЕ ПРЕКРАЩЕНИЯ ТРУДОВОГО ДОГОВОРА
} ПО ИНИЦИАТИВЕ РАБОТОДАТЕЛЯ

\begin{abstract}
Аннотация.
Актуальность исследования. Установление трудовых отношений в современном обществе - один из главных гарантов материального благополучия, а точнее финансового положения, безопасности. Работа заставляет человека чувствовать себя в безопасности, что, в свою очередь, влияет на более продуктивную и результативную работу. Но часто случается, что человек теряет этого гаранта своей безопасности и материального благополучия и увольняется. Большое количество безработных, зарегистрированных в Литве, свидетельствует о том, что потеря работы и связанная с ней безработица являются одной из проблем всего общества. Только в Литве в 2018 г. в 2019 г. было зарегистрировано 148242 безработных, а в 2019 г. - 144989 [1]. По данным Службы занятости, в январе 2021 г. в Литве было 277100 безработных, что составляет 16,1 процента. от общей численности населения страны в трудоспособном возрасте. Главная проблема. Прямое воздействие карантинных запретов и общий экономический спад приводят к увеличению числа увольнений. Расторжение трудового договора по просьбе работника или по соглашению между работником и работодателем достаточно ясно для институтов трудового права [2]. В контексте пандемии считается, что работник, как более слабая сторона в трудовых отношениях, может не только потерять стабильный источник дохода из-за закрытия бизнеса, но также может злоупотреблять законным правом работодателя увольнять работников. условия для возвращения этих рабочих на работу. Решены следующие задачи: 1. Определить понятие трудового договора, прекращаемого по инициативе работодателя. 2. Изучить существенные аспекты правового регулирования трудового договора при его расторжении по инициативе работодателя. 3. Выявить проблемы правового регулирования трудового договора после его расторжения по инициативе работодателя. 4. Анализировать проблемы трудового договора после его расторжения по инициативе работодателя в судебной практике. Целью данной работы является анализ основных проблем правового регулирования и применения трудового договора после его расторжения по инициативе работодателя. В документе сделан вывод, что прекращение трудового договора является прекращением прав и обязанностей сторон трудового договора, независимо от того, кто инициирует прекращение этих отношений. Между тем прекращение трудового договора по инициативе работодателя является окончанием отношений между сторонами трудового договора, когда работодателю предоставляется право инициировать прекращение этих отношений. Новизна Несмотря на то, что можно найти ряд научных статей о прекращении трудовых отношений, более подробный и глубокий анализ увольнений по инициативе работодателя отсутствует. Ввиду этого новинка. В результате регулирование увольнения работника, когда право инициативы по прекращению трудовых отношений переходит в «руки» работодателя, является достаточно всеобъемлющим и обеспечивает существование справедливого отношения к работнику. Используемая методология - анализ документов, систематический анализ, сравнительный, логикоаналитический метод и методы обобщения. Ключевые слова: работодатель, работник, трудовой договор, расторжение, инициатива работодателя.
\end{abstract}

(C) The Author(s) 2021

This is an open access article under the Creative Commons CC BY license
Received date 05.05.2021

Accepted date 19.05.2021

Published date 10.06.2021

How to cite: Perkumienè Dalia, Beriozovas Olegas \& Eglè, Stanionienè. Legal regulation problems of employment contract termination on employer's initiative. HUMANITIES STUDIES: Collection of Scientific Papers / Ed. V. Voronkova. Zaporizhzhia : Publishing house "Helvetica", 2021. 8 (85). P. 97-104. doi: https://doi.org/10.26661/hst-2021-8-85-10 